\title{
BIOCORROSION OF METAL SEWAGE TREATMENT CONSTRUCTIONS AND ITS IN HIBITION WITH PYRIDINIUM CHLORIDES
}

\author{
Olena Bondar ${ }^{1}$, Iryna Kurmakova ${ }^{1,}{ }^{*}$, Sergey Polevichenko ${ }^{1}$, Nataliya Demchenko ${ }^{1}$
}

https://doi.org/10.23939/chcht11.04.497

\begin{abstract}
On the metal sewage treatment constructions (Chernihiv, Ukraine) a biofilm is formed, which is corrosive because of the number of sulfate-reducing bacteria $\left(10^{7} \mathrm{cell} / \mathrm{cm}^{2}\right)$. By affecting sulfate-reducing activity of microorganisms, pyridinium chlorides at the concentration of $0.5 \mathrm{~g} / \mathrm{l}$ were revealed to provide St3ps steel inhibition efficiency of up to $98.7 \%$ under the corrosion caused by biofilm bacteria.
\end{abstract}

Keywords: biocorrosion, sulfate-reducing bacteria, pyridinium chloride, inhibitors.

\section{Introduction}

On the metal surfaces of technological equipment, placed in the neutral environment, a biofilm is formed, given the sufficient amount of nutrients under anaerobic conditions. The main component of such biofilm is sulfate-reducing bacteria, accompanied by the iron reducing bacteria, denitrifying and ammonifying bacteria. Under optimal conditions and provided biofilm functioning, such bacteria actively produce hydrogen sulphide. If the number of sulfate-reducing bacteria reaches $10^{6}-10^{7} \mathrm{cell} / \mathrm{cm}^{2}$, the biofilm becomes a medium for active corrosion [1]. The necessary amount of nutrients in the corrosive medium - sources of carbon and sulphur - facilitates the increase in the number of bacteria. Such conditions can be observed, particularly, on sewage treatment constructions, especially at the initial stage of the treatment of sewage, containing organic remains, oil products, sulphates, etc.

To estimate the technological threat and ensure the stable functioning of the technological equipment of the sewage treatment constructions, it is important to assess a qualitative and quantitative composition of the bacteria community in the biofilm, formed on the metal surfaces

\footnotetext{
${ }^{1}$ Chernihiv National T.G. Shevchenko Pedagogical University,

53 Hetmana Polubotka St., 14013 Chernihiv, Ukraine

i.kurmakova@gmail.com

(c) Bondar O., Kurmakova I., Polevichenko S., Demchenko N., 2017
}

[2]. The efficient anticorrosion inhibition may be ensured by isolating the metal, in particular, with inhibited paint and varnish materials. The choice of the biocorrosion inhibitors to modify anticorrosion materials should be made considering the peculiarities of microbiological factor, specific for such conditions [3]. At the same time, the fact that natural microbe communities can be more resistant to the biocide inhibitors than the collection strains and pure bacterial cultures, usually used in a model laboratory research, should be taken into account [4].

Pyridinium chlorides, previously synthesized and studied by us, can be promising for the research as biocide inhibitors for biocorrossion, as they have proved to be effective for the strains Desulfovibrio sp. M-4.1 and Desulfomicrobium sp.TC4 [5].

The aim of this paper is to examine the microbiological composition of the samples from the biofilm, formed on the metal sewage treatment constructions (Chernihiv, Ukraine) at different stages of sewage treatment, to measure the biocorrosion speed rate under their influence and to estimate the efficiency of pyridinium chlorides as biocide inhibitors.

\section{Experimental}

The water analysis on the sewage treatment constructions of the public company "Cherhihivvodokanal" (Chernihiv, Ukraine), where all the city domestic and industrial wastewater fall, was conducted following the requirements of current standards [7]. The ion concentration of $\mathrm{Fe}^{2+}$ and $\mathrm{Fe}^{3+}, \mathrm{Cu}^{2+}, \mathrm{Zn}^{2+}, \mathrm{Ni}^{2+}, \mathrm{Cr}^{2+}$, $\mathrm{NH}_{4}^{+}, \mathrm{PO}_{4}^{3-}$ was measured with the help of the photocolorimetric method; chloride ions concentration with the Mohr method of argentometry; sulphate ions with the complexonometric method [8]. Biological oxygen demand $\left(\mathrm{BOD}_{5}\right)$ was measured using the iodometric titrimetric analysis, while the chemical oxygen demand (COD) - the dichromate method.

Biofilm samples were gathered from the metal equipment surfaces at different stages of sewage treatment 
in June 2015. The first checkpoint was at the initial stage of sewage treatment (filtration grids), the second one - at the final stage (before ultraviolet water disinfection).

The number of bacteria (in selected biofilm samples, in corrosive medium, in biofilm, which appeared on the metal samples surface during the tests) was calculated using the method of decimal serial dilution during the bacteria seeding to the correspondent liquid selective mediums: sulfate reducing bacteria - to the Postgate "B" medium, iron reducing bacteria - to the Kalinenko medium, denitrifying - Giltay medium and ammonifying bacteria - to meat peptone broth [6].

The enrichment culture method in the liquid elective medium Postgate " $\mathrm{B}$ " provided the culture of sulfate reducing bacteria, used for modelling the biocorrosion process.

The studied biocorrosion inhibitors were pyridinium chlorides (Table 1), produced by the alkylation of substituted pyridines with $\alpha$-chloroacetanilides [5]. The purity of the compounds was confirmed by a combined gas chromatography (LC/MSD) method on the Agilent 1200 device with a mass-spectrometry detector Mass Quad G1956B (Agilent Technologies Inc.). The structure of the compounds was confirmed by $\mathrm{NMR}^{1} \mathrm{H}$ spectroscopy (Bruker-300).

The corrosion study was conducted using the gravimetric method. The steel St3ps plates (surface area $0.002 \mathrm{~m}^{2}$ ), polished to the 4-5 class of accuracy, were used. Before being placed in the corrosive medium, the steel samples were cleaned with alcohol and weighed with analytical scales accurate to $5 \cdot 10^{-5} \mathrm{~g}$. Corrosion rate with or without the inhibitors was calculated with the help of the formula: $k=\Delta m /(S \cdot \tau)$, where $\Delta m$ - sample weight loss, g; $S-$ area, $\mathrm{m}^{2} ; \tau-$ exposure time, h. Corrosion inhibition coefficient was calculated with the help of the formula: $\gamma=k / k^{\prime}$, where $k$ and $k^{\prime}$ is the corrosion rate with and without the inhibitor, respectively. The inhibition efficiency $(I E, \%)$ was calculated using the following equation: $(I E=(1-1 / \gamma) \cdot 100 \%)$.

Medium Postgate "B" $(\mathrm{pH}=7)$, sterile and inoculated with sulfate-reducing bacteria of the enrichment culture, was used as a testing corrosive medium. The initial titre of sulfate-reducing bacteria in a corrosive medium was $10^{9}$ cell $/ \mathrm{ml}$. Samples soaking time was 72 , $120,168,240,720$ and $1440 \mathrm{~h}$ at $300 \mathrm{~K}$. Inhibitor concentration -0.1 and $0.5 \mathrm{~g} / \mathrm{l}$.

The acidity was measured by $\mathrm{pH}$-meter/ionomer $\mathrm{pH} / \mathrm{ION} 340 \mathrm{i}$.

The concentration of biogenic hydrogen sulfide was measured using iodometric titration. The degree of influence $(S, \%)$ of the studied salts on bacteria sulfate reduction was calculated using the formula: $S=((C-$ $\left.C^{\prime}\right) / C$ ) $100 \%$, where $C$ and $C^{\prime}$ are the average hydrogen sulphide concentration with and without the inhibitor respectively, $\mathrm{mg} / \mathrm{l}$.

The biofilm cells, which appeared on the surface of steel samples during tests, were gathered into the fixed volume of $(20 \mathrm{ml}) 0.1 \mathrm{~N}$ of phosphate buffer $(\mathrm{pH}=7)$ with the help of ultrasound with a frequency of $25 \mathrm{kHz}(30 \mathrm{~s})$ twice with the $60 \mathrm{~s}$ interval using UZM-003/n. The resulting swab was used in cultivating and calculating the adhered bacteria cells [6].

Statistical analysis of experimental data (the corrosion rate) for the reliability level $95 \%$ was conducted with the help of Microsoft Excel. Linear regressive analysis was also performed. The experiment was conducted three times. The molecule lipophilicity coefficient $(\lg P)$ was calculated with the help of $\mathrm{ACD} / \log \mathrm{P}$ programme (Advanced Chemistry Development Inc.). Computer prediction of possible toxic action was done using the computer software GUSAR online, which includes the latest achievements in the field of QSAR modelling.

Table 1

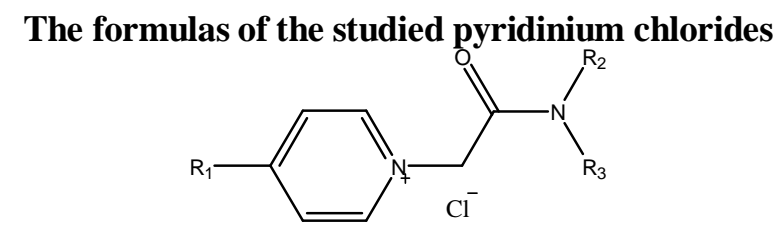

\begin{tabular}{|c|c|c|c|c|c|c|c|}
\hline $\mathrm{R}$ & In 1 & In 2 & In 3 & $\operatorname{In} 4$ & In 5 & In 6 & In 7 \\
\hline $\mathrm{R}_{1}$ & $-\mathrm{NH}_{2}$ & & & & & & \\
\hline $\mathrm{R}_{2}$ & & & & & & & \\
\hline $\mathrm{R}_{3}$ & & $-\mathrm{H}$ & $-\mathrm{H}$ & $-\mathrm{H}$ & $-\mathrm{H}$ & $-\mathrm{H}$ & $-\mathrm{H}$ \\
\hline
\end{tabular}




\section{Results and Discussion}

Wastewater, which flows to Chernihiv sewage treatment constructions, is characterized by the comparatively high figures of pollution indicators, in particular, biological oxygen demand $\left(\mathrm{BOD}_{5}=589.8 \mathrm{mg} / \mathrm{dm}^{3}\right)$ and chemical oxygen demand $\left(\mathrm{COD}=1232.2 \mathrm{mg} / \mathrm{dm}^{3}\right)$. These figures in the checkpoint 1 (the initial stage of sewage treatment) are 37-54 times higher than the figures of the cleaned water (checkpoint 2).

Before treatment, wastewater contains a significant amount of chlorides, sulphates, phosphates, ammonium and metal elements ions (Table 2). Almost neutral medium $(\mathrm{pH}=7.13)$ with deficient oxygen supply provides the optimal conditions for the formation of the biofilm, containing a significant number of sulfate reducing bacteria - the most aggressive constituent of corrosive microbe community $[1,2]$.

According to the results of microbiological study of the biofilm sample, the biofilm, formed on the metal surfaces at the initial stage of sewage treatment, is characterized with higher by the order number of sulfate reducing and ammonifying bacteria, the presence of denitrifying bacteria and lower by the order number of iron reducing bacteria (Fig. 1). Judging by the number of sulfate reducing bacteria $\left(>10^{6}\right)$ and their associates, such biofilm can be considered corrosively aggressive [1].

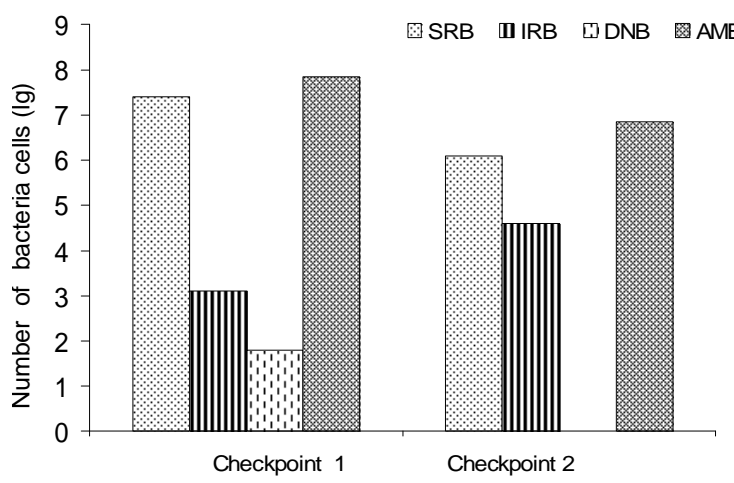

Fig. 1. Microbiological composition of the biofilm, formed on the metal surfaces of Chernihiv sewage treatment constructions (SRB - sulfate reducing; IRB - iron reducing;

DNB - denitrifying; AMB - ammonifying)

Steel St3ps corrosion in Postgate "B" medium under the influence of sulfate reducing enrichment culture, gathered from the stated biofilm, on the $240^{\text {th }}$ hour of the experiment reaches the speed rate of $19.73 \cdot 10^{-3} \mathrm{~g} /\left(\mathrm{m}^{2} \cdot \mathrm{h}\right)$, which is 1.7 times higher compared to the corrosion rate without bacteria (Fig. 2a). The concentration of biogenic hydrogen sulphide, produced primarily by the sulfate reducing bacteria in the process of metabolism, at the stated hour of the samples exposure reaches its maximum $-390 \mathrm{mg} / \mathrm{l}$ (Fig. 2b). This creates the aggressive corrosive medium with $\mathrm{pH}=4.5$.

Table 2

Ion concentration in the water of Chernihiv sewage treatment constructions (average for June, 2015)

\begin{tabular}{|c|c|c|c|c|c|c|c|c|c|}
\hline Ions & $\mathrm{Fe}^{2+}, \mathrm{Fe}^{3+}$ & $\mathrm{Cu}^{2+}$ & $\mathrm{Ni}^{2+}$ & $\mathrm{Cr}^{2+}$ & $\mathrm{Zn}^{2+}$ & $\mathrm{NH}_{4}^{+}$ & $\mathrm{Cl}^{-}$ & $\mathrm{SO}_{4}^{2-}$ & $\mathrm{PO}_{4}^{3-}$ \\
\hline $\begin{array}{c}\text { Concentration in the 1 } \\
\text { checkpoint, } \mathrm{mg} / \mathrm{dm}^{3}\end{array}$ & 5.12 & 0.047 & 0.044 & 0.074 & 0.062 & 39.58 & 101.11 & 25.00 & 16.92 \\
\hline $\begin{array}{c}\text { Concentration in the 2 } \\
\text { checkpoint, } \mathrm{mg} / \mathrm{dm}^{3}\end{array}$ & 0.15 & not found & not found & not found & not found & 7.63 & 92.49 & 44.40 & 4.62 \\
\hline
\end{tabular}

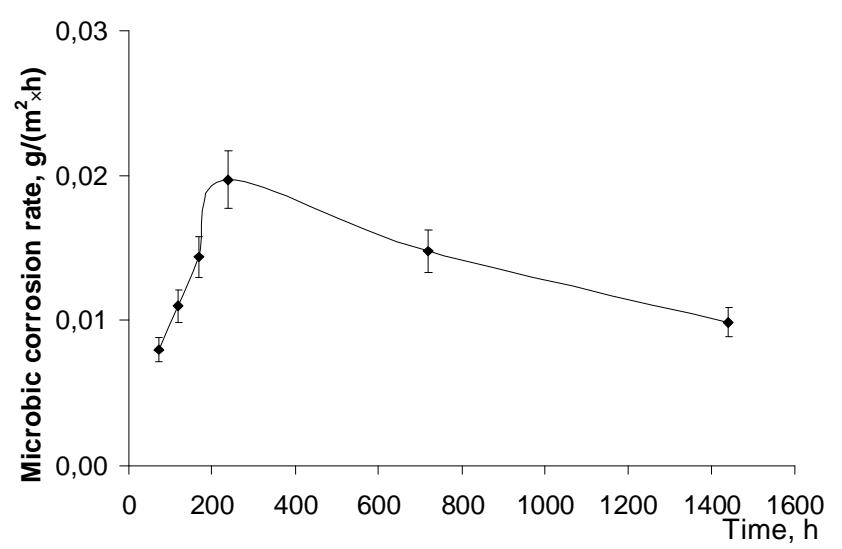

a)

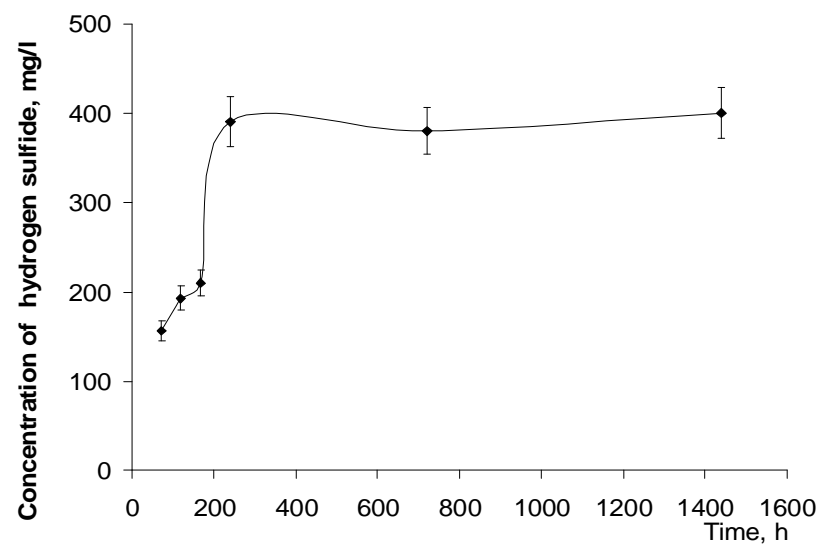

b)

Fig. 2. Steel St3ps biocorrosion indices in Postgate "B" medium: correlation between the corrosion rate and the time (a); correlation between the biogenic hydrogen sulphide concentration in the corrosive medium and the time of samples exposure (b) 
The effectiveness of pyridinium chlorides under steel St3ps biocorrosion in medium Postgate "B" (samples soaking time - $240 \mathrm{~h}$ )

\begin{tabular}{|c|c|c|c|c|c|c|c|c|c|c|}
\hline \multirow{3}{*}{ In } & $k \cdot 10^{3}, \mathrm{~g} /\left(\mathrm{m}^{2} \cdot \mathrm{h}\right)$ & $\gamma$ & $I E, \%$ & $k \cdot 10^{3}, \mathrm{~g} /\left(\mathrm{m}^{2} \cdot \mathrm{h}\right)$ & $\gamma$ & $I E, \%$ & $C\left(\mathrm{H}_{2} \mathrm{~S}\right), \mathrm{mg} / \mathrm{l}$ & $S, \%$ & $k \cdot 10^{3}, \mathrm{~g} /\left(\mathrm{m}^{2} \cdot \mathrm{h}\right)$ & $\gamma$ \\
\hline & \multicolumn{8}{|c|}{ With the sulfate reducing enrichment culture } & \multirow{2}{*}{\multicolumn{2}{|c|}{ Without bacteria $(0.5 \mathrm{~g} / \mathrm{l})$}} \\
\hline & \multicolumn{3}{|c|}{$0.1 \mathrm{~g} / \mathrm{l}$} & \multicolumn{5}{|c|}{$0.5 \mathrm{~g} / 1$} & & \\
\hline- & $19.73 \pm 0.79$ & - & - & $19.73 \pm 0.79$ & - & - & 390 & - & $11.79 \pm 0.49$ & - \\
\hline 1 & $5.79 \pm 0.29$ & 3.41 & 70.7 & $2.21 \pm 0.09$ & 8.93 & 88.8 & 223 & 42.8 & $3.01 \pm 0.16$ & 3.92 \\
\hline 2 & $6.07 \pm 0.30$ & 3.25 & 69.2 & $4.72 \pm 0.18$ & 4.18 & 76.1 & 158 & 59.5 & $8.93 \pm 0.30$ & 1.32 \\
\hline 3 & $6.80 \pm 0.34$ & 2.90 & 65.5 & $1.07 \pm 0.05$ & 18.44 & 94.6 & 15 & 96.2 & $24.56 \pm 0.81$ & 0.48 \\
\hline 4 & $1.93 \pm 0.10$ & 10.22 & 90.2 & $0.33 \pm 0.02$ & 59.79 & 98.3 & 11 & 97.2 & $28.40 \pm 0.80$ & 0.42 \\
\hline 5 & $4.61 \pm 0.27$ & 4.28 & 76.6 & $0.62 \pm 0.03$ & 31.82 & 96.9 & 18 & 95.4 & $13.54 \pm 0.28$ & 0.87 \\
\hline 6 & $1.46 \pm 0.09$ & 13.51 & 92.6 & $0.26 \pm 0.01$ & 75.88 & 98.7 & 6 & 74.6 & $21.00 \pm 0.80$ & 0.56 \\
\hline 7 & $5.65 \pm 0.33$ & 3.49 & 71.3 & $2.19 \pm 0.09$ & 9.01 & 88.9 & 99 & 98.5 & $19.79 \pm 0.82$ & 0.60 \\
\hline
\end{tabular}

The studied pyridinium chlorides (In 1-In 7) at the concentration of $0.1 \mathrm{~g} / \mathrm{l}$ provide steel $\mathrm{St} 3 \mathrm{ps}$ inhibition efficiency of 65.5 up to $92.6 \%$, at the concentration of $0.5 \mathrm{~g} / \mathrm{l}$-inhibition efficiency of 76.1 up to $98.7 \%$ (Table $3)$. Their inhibition efficiency is caused by the predominant impact on the biological factor. This can be proven with the fact that the studied inhibitors in medium Postgate "B" without bacteria are either ineffective (In 1, In 2), or increase the corrosion rate by 1.2-2.4 times (In 3 -In 7). According to the authors' classification [4], the studied pyridinium chlorides can be treated as $3^{\text {rd }}$ group inhibitors, to which such effective industrial inhibitors as Katapyn-M, KPI-2M, etc. belong.

Under the biocorrosion the compounds In 6 and In 4 turned out to be the most effective. Their effectiveness is caused by the significant ( 98.5 and $97.2 \%$, respectively) impact on the sulfate reducing activity of the enrichment culture bacteria, which is measured with the help of biogenic hydrogen sulphide concentration. At the same time $\mathrm{pH}$ of Postgate "B" medium decreases only to 5.5.

A correlation between the inhibition efficiency of the studied pyridinium chlorides and the biogenic hydrogen sulphide concentration has been established (Fig. 3). The regression equation for the inhibitor concentration of $0.5 \mathrm{~g} / \mathrm{l}$ is: $I E=-0.09 C+98.46$. The approximation coefficient value $\left(R^{2}\right)$ is 0.91 , which indicates the high degree of correlation, according to the Cheddock scale.

While extracting the studied compounds of the two groups, considering the structural peculiarities of the molecules: In 2 , In 3 , In 4 ( $\mathrm{R}_{1}$ - hydrazinocarbonyl fragment) and In 5, In 6, In 7 ( $\mathrm{R}_{1}$ - benzylaminecarbonyl fragment), a correlation between the steel inhibition efficiency under the biocorrosion and the lipophilicity coefficient has been established (Fig 4.). The approximation coefficient value $\left(R^{2}\right)$ for both groups of compounds is more than 0.93 . According to $[9,10]$, the increase in $\lg P$ value will lead to the increase of the possibility of molecule penetration through the bacterial cell membrane, and i.e. the increase of compounds antimicrobial activity. Thus, the data acquired also prove the dominant impact of the compounds on the biological factor. The similar correlations were established during the study of triazoloazepinium derivatives as biocorrosion inhibitors.

The study of the biofilm, formed on the metal samples in Postgate " $\mathrm{B}$ " medium with the bacteria enrichment culture, revealed that In 4 and In 6 lead to a biofilm formation without sulfate reducing bacteria (Fig. 5).

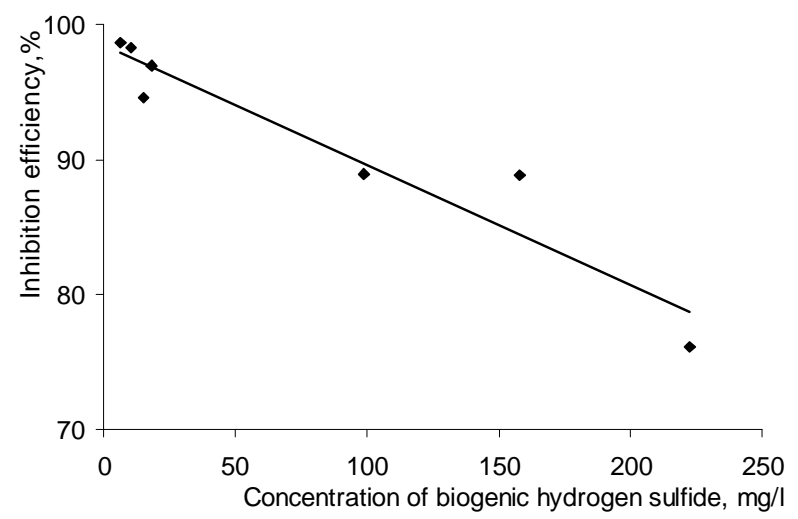

Fig 3. The correlation between the steel St3ps inhibition efficiency under the biocorrosion and the biogenic hydrogen sulphide concentration (inhibitor concentration $0.5 \mathrm{~g} / \mathrm{l}$ )

Under the impact of In 6 the number of sulfate reducing bacteria in the biofilm turned out to be less than the control sample by 8 orders $\left(10^{9} \mathrm{cell} / \mathrm{cm}^{2}\right)$.

The most effective of the studied pyridinium chloride compounds In 4 and In 6 affected greatly the number of bacteria in the corrosive medium (suspension). Different effect of pyridinium chloride on the number of bacteria in the biofilm and suspension can be explained by different sensitivity of these bacteria forms of growth and is consistent with [1]. 


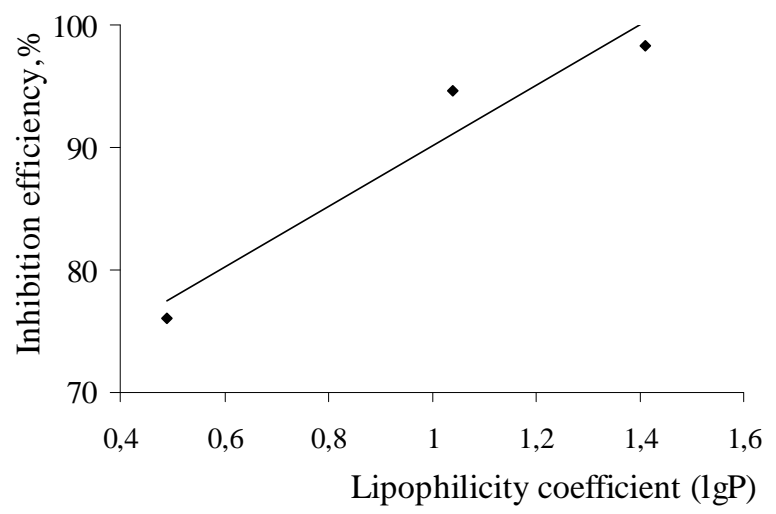

a)

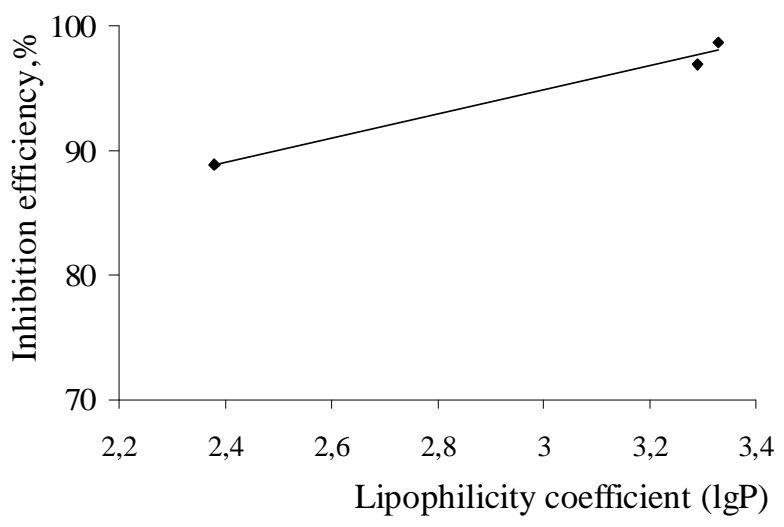

b)

Fig. 4. The correlation between the steel St3ps inhibition efficiency under the biocorrosion and the lipophilicity coefficient for the compounds: with hydrazinocarbonyl fragment (In 2, In 3, In 4) (a) and with benzylaminecarbonyl fragment (In 4, In 5, In 6) (b)

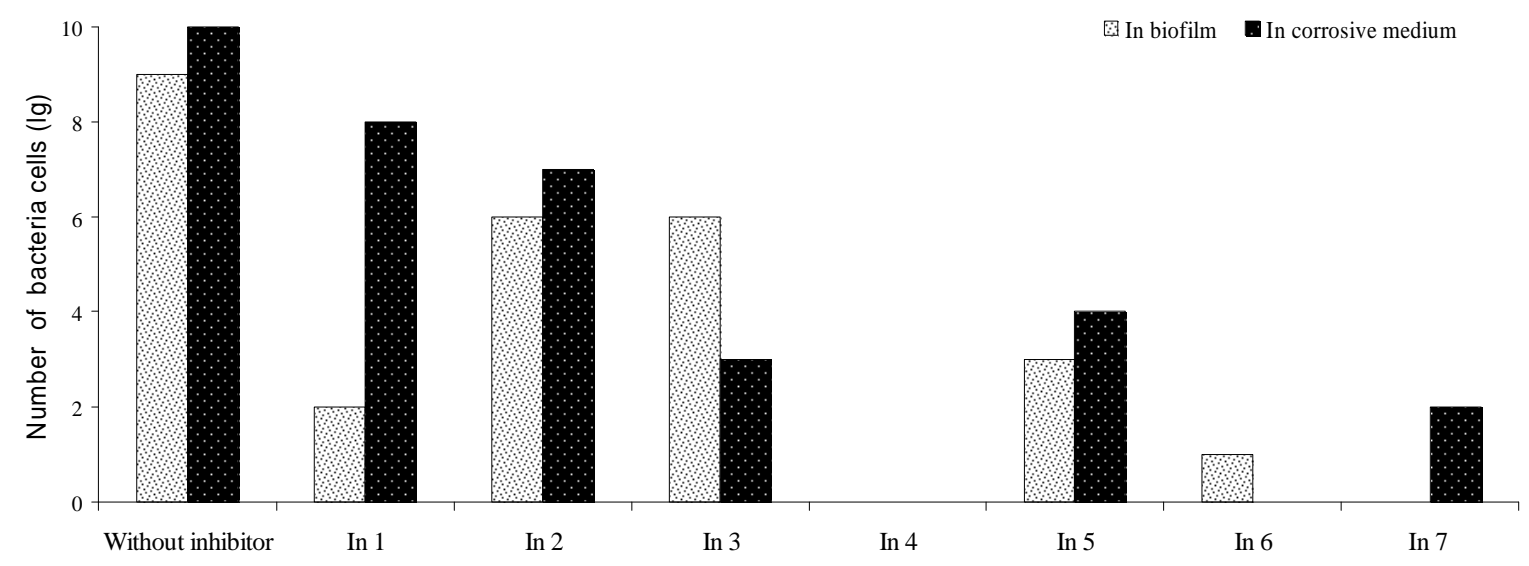

Fig. 5. Pyridinium chloride $(0.5 \mathrm{~g} / \mathrm{l})$ impact on the number of sulfate reducing bacteria in the biofilm and corrosive medium Postgate 'B”' (suspension) under steel St3ps biocorrosion

At the same time no apparent correlation between the steel inhibition efficiency under biocorrosion and the number of sulfate reducing bacteria in the biofilm and the suspension was established.

Prediction of the possible toxicity of pyridinium chlorides allows to refer them to slightly toxic ones (toxicity class 4) (LD50 is within $585.2-1344.0 \mathrm{mg} / \mathrm{kg}$ in the calculation provided Rat Oral). So, they meet the requirements to inhibitor biocides, and can be suggested for modification of coatings.

\section{Conclusions}

On the metal sewage treatment constructions (Chernihiv, Ukraine) at the initial stage of sewage treatment process the biofilm, corrosive by the number of sulfate reducing bacteria $\left(10^{7} \mathrm{cell} / \mathrm{cm}^{2}\right)$, is formed. Under such conditions the biocorrosion inhibitors are pyridinium chlorides, which at the concentration of $0.5 \mathrm{~g} / \mathrm{l}$ ensure up to $98.7 \%$ mild steel inhibition by affecting the sulfate reducing bacteria of the biofilm microbe community. The highest inhibition efficiency was established for 1-\{2-[(4chlorophenyl)amino]-2-oxoethyl $\}-4-(N$-phenylglycil) pyridinium chloride.

\section{References}

[1] Kozlova I., Radchenko O., Stepura L. et al.: Heokhimichna Diyalnist Mikroorganizmiv ta ii Prykladni Aspekty. Naukova dumka, Kyiv 2008.

[2] Lin J., Ballim R.: African J. Biotechnol., 2012, 91, 15736. [3] Purish L., Asaulenko L., Abdulina D., Iutinskaia H.: Mikrobiol. Zhurn., 2014, 76, 11.

[4] Purish L. Pogrebova I., Kozlova I.: Mikrobiol. Zhurn., 2002, 64, 67. [5] Polevichenko C., Bondar O., Kurmakova I., Demchenko A.: XXIV Ukrainska konferentsia z organichnoi khimii, Ukraine, Poltava 2016, 158. 
[6] Egorov N.: Rukovodstvo k Prakticheskim Zanyatiyam po Microbiologii. Izd-vo Mosk. Univ., Moskva 1983.

[7] Pochekailova L., Kozhedub U.: Vodopostachannia ta Vodovidvedennia, 2011, 3, 59.

[8] Vasilev V.: Fizyko-Khimicheskie Metody Analiza. Drofa, Moskva 2002.

[9] Orlov V., Lipson V., Ivanov V.: Meditsinskaia Khimia. Folio, Kharkiv 2005.

[10] Paratii V., Synchenko V., Prodanchuk V. et al: Mikrobiol. Zhurn., 1989, 51, 48.

[11] Demchenko N.: Vplyv Chetvertynnykh Solei Pirydyniiu ta Triazoloazepiniiu na Rozvytok Koroziinoho Microbnogo

Ugrupovannia Hruntu. Kyiv 2012.

Received: December 09, 2016/ Revised: December 29, 2016

/ Accepted: M arch 01, 2017

\section{БІОКОРОЗІЯ МЕТАЛЕВИХ КОНСТРУКЩІЙ ОЧИСНИХ СПОРУД ТА ІІЇ ІНГІБУВАННЯ ХЛОРИДАМИ ПІРИДИНІЮ}

Анотація. На металевих конструкціях очисних споруд (м. Чернігів, Украӥна) формується біоплівка, яка є корозійно небезпечною за чисельністю сульфатвідновлювальних бактерій $\left(10^{7} \mathrm{\kappa} / \mathrm{cm}^{2}\right)$. Показано, щзо хлориди піридинію за концентрачії 0,5 г/л внаслідок впливу на сульфатредукуючу активність мікроорганізмів забезпечують до 98,7 \% захисту сталі Ст3nc при корозї інічійованої культурою бактерій виділеною 3 біоплівки.

Ключові слова: біокорозія, сульфатвідновлювальні бактерії, хлориди піридинію, інгібітори. 